\title{
Naphthaleneacetic Acid Thins Pecan Fruit
}

\author{
Ray E. Worley ${ }^{1}$ \\ Horticulture Department, University of Georgia, Coastal Plain Experiment \\ Station, Tifton, GA 31793-0748
}

Additional index words. NAA, preharvest drop, Carya illinoinensis

No satisfactory chemical fruit thinner has been developed for pecan [Carya illinoensis (Wangenh.) C. Koch]. At 30 to $50 \mu \mathrm{g} \cdot \mathrm{g}^{-1}$, (2chloroethyl)phosphonic acid (ethephon) thinned pecan fruit, but overthinning and leaf abscision were problems (Hinrichs et al., 1971). Naphthaleneacetic acid (NAA) has been used as a sprout inhibitor (Phillips and Tucker, 1974; Raese, 1975; Young et al., 1978) and an antidote to leaf abscision caused by ethephon (Wood, 1989). NAA is labeled for thinning of apple (Malus domestica Borkh.), Citrus, and olive (Olea europea L.) and for preharvest drop prevention for apple and pear (Pyrus communis C.). I report on the pecan fruitthinning potential of NAA.

NAA(K-Salt Fruit Fix 800; Amvac Chemical Corp., City of Commerce, Calif.) was sprayed to runoff on irrigated trees at $0,20,50$, 100,200 , and $500 \mu \mathrm{g}$ a.i./g on 19 May (pollination complete stage), 16 June (slow fruit growth stage), and 20 July (rapid fruit growth stage) in 1992 and at $0,50,100,500$, and 1000 $\mu \mathrm{g} \cdot \mathrm{g}^{-1}$ on 22 July 1993 and 1 Aug. 1994. Replications were individual trees $(>30$ years old), with each concentration applied to a different sector of each tree. Replications were four for each date in 1992, seven in 1993, and six in 1994. Fruit clusters were labeled on sufficient terminals to include 100 fruit per treatment per tree. Fruit remaining $\approx 1$ month later were counted.

Phytotoxicity (cupping and marginal necrosis) was noticed only for $500 \mu \mathrm{g} \cdot \mathrm{g}^{-1}$, applied 19 May 1992. NAA at $500 \mu \mathrm{g} \mathrm{g}^{-1}$ increased fruit drop over the control by 29 percentage points for 19 May, 34 for 16 June, and 11 for 20 July 1992 (Table 1), but had no effect in the other 2 years. Regression analysis in 1992 suggested increasing NAA concentration, particularly the three highest concentrations, increased percent drop and reduced fruit per terminal (Table 1$)$. The major difference $(t$ test) was between $500 \mu \mathrm{g} \cdot \mathrm{g}^{-1}$ and the other

Received for publication 14 Nov. 1994. Accepted for publication 6 June 1995. The cost of publishing this paper was defrayed in part by the payment of page charges. Under postal regulations, this paper therefore must be hereby marked advertisement solely to indicate this fact.

${ }^{1}$ Professor. treatments. An additional count (not shown in tables) that measured the drop between 16 July and 26 Aug. 1992 indicated the thinning effect of the 16 June spray was over by 16 July; thus, there was not a residual effect of the NAA sprays after 30 days.

None of the treatments affected fruit thinning in 1993 (data not shown), but an average of $25 \%$ of fruit aborted with NAA at 1000 $\mu \mathrm{g} \cdot \mathrm{g}^{-1}$ in 1994 , compared with only $4 \%$ for the control. The number of fruit per terminal was reduced by 0.6 (Table 2). None of the lower concentrations thinned fruit in 1994. Although the linear trend was significant, the data and $t$ test clearly show that the major difference was between trees receiving the $1000 \mu \mathrm{g}$ NAA/g and the other treatments. Size, kernel percentage, and kernel grade was determined only in 1993 and 1994 and were not affected by treatments (data not shown).

The high probability of natural drop (Sparks and Heath, 1972) and phytotoxicity would usually preclude using NAA as an early season fruit thinner. If the crop were still heavy after the first and second drop, using an effective chemical thinner in June or July would be desirable. Reasons for the inconsistent results over years must be resolved before NAA's commercial application. Crop load after the July spray was 1.9 fruit per terminal for the control in 1992 when $500 \mu \mathrm{g} \mathrm{NAA} / \mathrm{g}$ was effective, 2.4 per terminal in 1994 when 1000 $\mu \mathrm{g} \cdot \mathrm{g}^{-1}$ was effective, and 3.4 in 1993 when application date, 1992.

y Phytotoxicity occurred at this NAA concentration. neither was effective. A higher crop load may require a higher concentration to thin; however, the regression of percent drop and fruit per terminal after spraying with that of fruit per terminal before spraying in 1994 was not significant. The cultivar was 'Stuart' in 1993 when NAA was ineffective and 'Farley' in the other years; thus, cultivar effects must be studied further.

\section{Literature Cited}

Hinrichs, H.A., D.W. Ramming, and D.A. Hopfer. 1971. Effects of ethephon on thinning nuts and loosening shucks of pecan. Annu. Rpt. Northern Nut Growers Assn. 62:105-108.

Phillips, R.L. and D.P.H. Tucker. 1974. Chemical inhibition of sprouting of pruned lemon trees. HortScience 9:199.

Raese, J.T. 1975. Sprout control of apple and pear trees with NAA. HortScience 10:396-398.

Sparks, D. and J.L. Heath. 1972. Pistillate flower and fruit drop of pecan as a function of time and shoot length. HortScience 7:402-404.

Wood, B.W. 1989. Ethephon and NAA facilitate early harvesting of pecan. J. Amer. Soc. Hort. Sci. 114:279-282.

Young, W.A., J.E. Love, and J.E. Boudreaux. 1978. Use of naphthaleneacetic acid in training of young pecan trees. HortScience 13:262.

Table 2. Effect of NAA concentration on percentage of fruit aborted and number of fruit per terminal, 1994.

\begin{tabular}{lcc}
\hline $\begin{array}{l}\text { NAA } \\
\text { concn } \\
\mu g^{-1}\end{array}$ & $\begin{array}{c}\text { Fruit } \\
\text { aborted } \\
(\%)\end{array}$ & $\begin{array}{c}\text { Fruit } \\
\text { no./terminal }\end{array}$ \\
\hline 0 & 4 & 2.4 \\
50 & 10 & 2.2 \\
100 & 5 & 2.4 \\
500 & 11 & 2.3 \\
1000 & 25 & 1.8 \\
$\mathrm{~L}^{y}$ & $* *$ & $* *$ \\
$\mathrm{Q}$ & $\mathrm{NS}$ & NS \\
\hline
\end{tabular}

${ }^{\mathrm{z}} \mathrm{A} t$ test revealed differences only between the 1000 $\mu \mathrm{g} \cdot \mathrm{g}^{-1}$ concentration and the other concentrations. Ns, **Nonsignificant and significant linear (L) and quadratic (Q) response at $P=0.01$, respectively.

Table 1. Percentage of fruit dropped and fruit per terminal $(\mathrm{F} / \mathrm{T})$ as affected by NAA concentrations and spray

\begin{tabular}{|c|c|c|c|c|c|c|}
\hline \multirow{3}{*}{$\begin{array}{l}\text { NAA } \\
\text { concn } \\
\left(\mu g^{\prime} g^{-1}\right)\end{array}$} & \multicolumn{6}{|c|}{ Spray date $^{\mathrm{z}}$} \\
\hline & \multicolumn{2}{|c|}{19 May } & \multicolumn{2}{|c|}{16 June } & \multicolumn{2}{|c|}{20 July } \\
\hline & $\%$ Drop & $\mathrm{F} / \mathrm{T}$ & $\%$ Drop & $\mathrm{F} / \mathrm{T}$ & $\%$ Drop & $\mathrm{F} / \mathrm{T}$ \\
\hline 0 & 62 & 1.42 & 36 & 1.79 & 33 & 1.89 \\
\hline 20 & 62 & 1.31 & 39 & 1.71 & 27 & 2.04 \\
\hline 50 & 60 & 1.47 & 41 & 1.73 & 23 & 2.27 \\
\hline 100 & 62 & 1.32 & 30 & 2.11 & 29 & 2.10 \\
\hline 200 & 69 & 1.18 & 34 & 1.92 & 33 & 1.92 \\
\hline 500 & $91^{y}$ & 0.45 & 67 & 0.93 & 44 & 1.50 \\
\hline $\mathrm{L}$ & NS & NS & $* *$ & $* *$ & $*$ & $* *$ \\
\hline Q & $* *$ & $* *$ & $* *$ & $* *$ & $* *$ & $* *$ \\
\hline
\end{tabular}

${ }^{2}$ Data for the 19 May spray was the percentage of fruit on 19 May that had dropped by 25 June; similarly, for 16 June spray/16 July count, and 20 July spray/25 Aug. count.

ss, *, ** Nonsignificant or significant linear (L) and quadratic (Q) response at $P=0.05$ or 0.01 , respectively. 